\title{
Challenges and Opportunities Created by the COVID-19 Pandemic
}

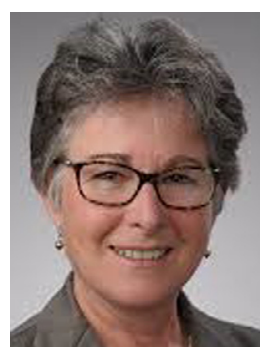

The COVID-19 pandemic is an unprecedented challenge with immediate impacts on public and economic health. It has radically changed relationships across the globe. Our personal relationships have been radically altered as we've learned to socially distance ourselves, wear face masks when walking or shopping, smile more with our eyes, and nod or wave our greetings. We're holding Zoom meetings and classes and forming exclusive social "pods" of quarantine buddies and sharing meals virtually.

Our relationship with food is changing too. In a matter of months, COVID-19 has brought about a change in behavior many nutrition educators view as critical to public health and sustainability: cooking. I dearly hope that the current surge in home cooking spells a long-term reversal in the overall decline home cooking that stretches back to $1965 .^{1}$

A recent Hunter survey ${ }^{2}$ suggests that it may. More than half of the respondents said they were cooking more than before the pandemic. Of particular interest to nutrition educators, three-quarters of respondents claimed they had become more confident in the kitchen, and 51\% said they will continue to cook more after the crisis ends. ${ }^{2}$ As people around the world have adjusted to COVID-19driven stay-at-home guidelines, family meals-not just dinner-have become part of the new normal. For some, the shift to family meals may be one of the few good things to come out of the pandemic. ${ }^{3}$

Not all changes are positive, however. Sales of processed and "comfort" foods such as potato chips, cookies, popcorn, pretzels, candy ${ }^{4}$ have taken off since early March. ${ }^{5}$ Scoffing at nutrition standards in the midst of a pandemic is understandable. As nutrition writer Bettina Elias Siegel points out, stress often increases desire of highly palatable, yet unhealthy, food. ${ }^{6}$ While crushing stresses of "job insecurity, cramped living spaces, poorer sleep, a dearth of childcare, and lack of assured access to medical care $^{\prime 6}$ are new for many Americans, for low-income families they were a way of life well before COVID-19. The opportunity for nutrition education is to advocate for nutrition quality and access to healthy food for all, in the best and worst of times. Now is the time ensure our food safety net is adequate for the purchase of healthy food to cook.

The pandemic is changing our relationship with food well beyond the kitchen. Driven perhaps by increased uncertainty about the food supply, increased reliance on the emergency food system or simply by a need to control something basic to survival, home gardening is on rise at rates not seen since the Great Recession of 2008. Whether on a patch of lawn converted to vegetable beds, in containers on apartment deck, or in window boxes, more of us are growing some of our food. At the time of this writing, local suppliers are reporting seed shortages and consumers are starting their "pandemic gardens."7 The timing couldn't be better to integrate garden-based learning with nutrition education programming. ${ }^{8}$ Further, SNAP-Ed practitioners can remind recipients their benefit can be used for vegetable seeds.

Reports of breakdowns in conventional food supply chains and COVID-19 hotspots among frontline food workers particularly in large industrial meat packing plants have exposed food system vulnerabilities, inequities and ethical breaches. ${ }^{9}$ The crisis that unfolded in big meat's supply chain shines light on yet another opportunity for nutrition educators to work at policy, systems and environmental change levels to create change.

As the food system policy director at the Johns Hopkins Center for a Livable Future, Bob Martin, suggests, "This virus is a warning shot, and it provides us with an opportunity to change our food system in ways that are less susceptible to disruption."10 As nutrition educators, academics, researchers and advocates we can help bring this change by helping less concentrated, more diverse, locally controlled and resilient food systems emerge and thrive.

Jennifer L. Wilkins, PhD, RD
President, Society for Nutrition
Education and Behavior

\section{REFERENCES}

1. Smith LP, Ng SW, Popkin BM. Trends in US home food preparation and consumption: analysis of national nutrition surveys and time use studies from 19651966 to 2007-2008. Nutr J. 2013; 12:45.

2. Hunter. Special Report, America Gets Cooking: The impact of COVID-19 on Americans' food habits. Food study 2020: complete study results. https:// www.slideshare.net/HUNTERNY/ hunter-food-study-special-report-america-gets-cooking-231713331. Accessed May 6, 2020

3. Davies D. Cooking During COVID-19: Family meals and fantasies of future dinner parties. Fresh Air. April 7, 2020. https://www.npr.org/2020/04/07/ 828498977/cooking-during-covid-19family-meals-and-fantasies-of-futuredinner-parties. Accessed May 6, 2020.

4. Skerritt J, Mulvay L, Almeida I. Americans drop kale and quinoa to lock down with chips and Oreos. Bloomberg 
News. March 21, 2020. https://www. bloomberg.com/news/articles/2020-0321/americans-drop-kale-and-quinoa-tolock-down-with-chips-and-oreos. Accessed May 6, 2020.

5. Creswell J. I just need the comfort': processed foods make a pandemic comeback. New York Times. April 7, 2020. https://www.nytimes.com/ 2020/04/07/business/coronavirusprocessed-foods.html?action $=$ click $\&$ module $=$ Top $\% 20$ Stories\&pgtype $=$ Homepage. Accessed May 6, 2020.

6. Seigel BE. What Our stress-eating and "anxiety baking" say about socioeconomics and poor diet. The Lunch
Tray. April 8, 2020. https://www.thelunchtray.com/what-our-stress-eatingand-anxiety-baking-say-about-socioeconomics-and-poor-diet/. Accessed May 6, 2020.

7. Picchi A. Seed companies can't keep up as more Americans turn to growing their own food. CBS News. April 14, 2020. https://www.cbsnews.com/news/coronavirus-seeds-americans-grow-food/. Accessed May 6, 2020.

8. Libman K. Growing youth growing food: how vegetable gardening influences young people's food consciousness and eating habits. Appl Environ Educ Commun. 2007;6:87-95.
9. Bellows A, Welsh R, Weissman E, et al. From farm to factory to table, coronavirus pandemic challenges US food system (Commentary). Syracuse.com. April 6, 2020. https://www.syracuse.com/opinion/2020/04/from-farm-to-factory-totable-coronavirus-pandemic-challengesus-food-system-commentary.html. Accessed May 6, 2020.

10. Holpuch A. Meat-free future? Coronavirus exposes America's fragile food system. The Guardian. May 10, 2020. https://www.theguardian.com/world/ 2020/may/10/coronavirus-americameat-food-system-farming. Accessed May 6, 2020.

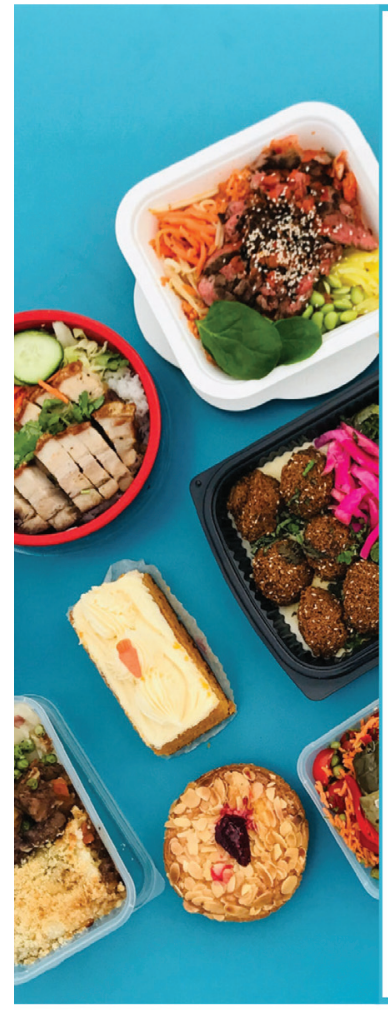

\section{Submissions Extended to September 15, 2020: Sustainable Management of Food themed issue}

An important aspect of the sustainable management of food that is within JNEB's scope is investigation of reductions in food loss and waste that involve behavioral changes.

Authors do not need to make a clear connection between their intervention and increasing sustainability, but acknowledgment of this link should be evident in the Introduction and Implications sections, with caution not to overstate results.

Examples of papers that would fall with this topic include:

Food Waste in a School Nutrition Program After Implementation of New Lunch Program Guidelines. Carmen J. Byker, Alisha R. Farris, Michael Marcenelle, George C. Davis, Elena L. Serrano. J Nutr Educ Behav. 2014;46(5):406-411.

Factors Influencing Fluid Milk Waste in a Breakfast in the Classroom School Breakfast Program. Stacy A. Blondin, Jeanne P. Goldberg, Sean B. Cash, Timothy S. Griffin, Christina D. Economos, J Nutr Educ Behav. 2018;50(4):349-356.

A Plate Waste Evaluation of the Farm to School Program. Jaclyn D. Kropp, Saul J. Abarca-Orozco, Glenn D. Israel, David C. Diehl, Sebastian Galindo-Gonzalez, Lauren B. Headrick, Karla P. Shelnutt. J Nutr Educ Behav. 2018;50(4):332-339. 